\title{
JOUPRENEUR: AN ORIGINAL METHODOLOGY FOR RAISING ENTREPRENEURIAL INTENTIONS AMONG JOURNALISM STUDENTS
}

\author{
Joupreneur: una metodología docente para \\ incrementar la intención emprendedora en \\ estudiantes de periodismo
}

Manuel Goyanes y Marcello Serra

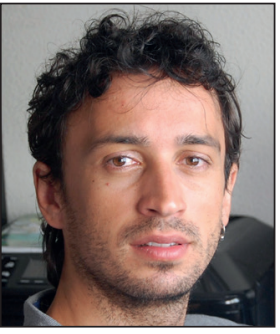

Manuel Goyanes, PhD, teaches at the Carlos III University in Madrid and his main interests are in media management and sociology of organizations. He has written about leadership, news overload and business models. He has attended several international congresses and published in international journals such as Journalism practice, International journal on media management, and International journal of communication. http://orcid.org/0000-0001-6537-9777

manuel.goyanes@uc3m.es

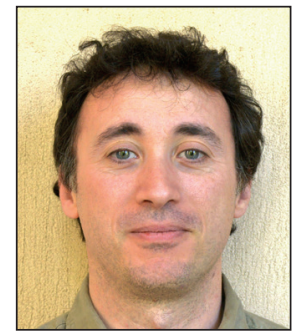

Marcello Serra, PhD, teaches at the Carlos III University in Madrid and his main interests are in semiotics and media theory. Among other subjects, he has written about comics, transparency, social movements, and Diego Maradona as a contemporary idol. He has coordinated several books and, in particular, he is the editor, with Mario Pireddu, of Mediologia. Una disciplina attraverso $i$ suoi classici (Spanish version: Mediología. Cultura, tecnología y comunicación).

http://orcid.org/0000-0002-6412-5078

marcello.serra@uc3m.es

Carlos III University of Madrid C/Madrid, 133. 28903 Getafe (Madrid), Spain

\begin{abstract}
This article describes in detail, and empirically validates a methodology for raising entrepreneurial intentions among journalism students. The research is based on pre-post surveys of four groups of students ( 88 in total), ages $18-25$, from the Carlos III University of Madrid, and measures the change in the students' intentions after a period of three months in a sixcredit, third-year, journalism class. The findings contribute to the theories of education and have wider implications for the practice of entrepreneurship teaching among journalism students.
\end{abstract}

\section{Keywords}

Entrepreneurship; Entrepreneurial intention; Journalism; Education; University students.

\section{Resumen}

El presente artículo describe en detalle y valida empíricamente una metodología docente para incrementar la intención emprendedora de estudiantes de periodismo. La investigación se basa en un diseño experimental mediante encuestas pre-post en cuatro grupos de 18-25 estudiantes (88 en total) de la Universidad Carlos III de Madrid, y mide el cambio en la intención después de un período de tres meses de clase. Los resultados contribuyen a la bibliografía teórica sobre educación y tienen amplias implicaciones para la práctica de la enseñanza sobre emprendimiento en estudiantes de periodismo.

\section{Palabras clave}

Emprendimiento; Intención emprendedora; Periodismo; Educación; Estudiantes universitarios.

Goyanes, Manuel; Serra, Marcello (2016). “Joupreneur: An original methodology for raising the entrepreneurial intention among journalism students". El profesional de la información, v. 25, n. 4, pp. 599-605.

\section{http://dx.doi.org/10.3145/epi.2016.jul.09}




\section{Introduction}

In recent years, fostering entrepreneurship education has become a topic of the highest priority in public policy throughout most industrial countries (Galán-Gamero; Aguado-Guadalupe, 2014). Research typically supports the idea that high levels of entrepreneurship can be achieved through education (Tkachev; Kolvereid, 1999) and, as a result, a wide range of education initiatives related to entrepreneurship have been initiated. In addition, well-educated entrepreneurs have established themselves as important leaders throughout the world.

In the United States, entrepreneurship and entrepreneurship education (EE) are widely recognized to have made tremendous progress (Lüthje; Franke, 2004). Spain, however, has been comparatively slow to recognize these opportunities. Until recently, fostering entrepreneurial values has not been regarded as a primary task in Spanish universities. In this sense, the vast majority of Spanish public universities have lacked specific education on this field, and "entrepreneurship" as an educational discipline has not been recognized by the official educational authorities (ANECA). However, in recent years, fostering entrepreneurial inclinations through education and training has received increasing attention from Spanish public institutions and, even more, from private ones. Since the beginning of the new century and particularly as a result of the bursting of the Spanish housing bubble and the subsequent economic downturn, the public authorities that champion entrepreneurship education as a fundamental contributor for the future economic development are growing louder (Goyanes, 2015).

The important assumption underlying the promotion of entrepreneurship education follows the idea that participating in an entrepreneurship course can increase a student's intention to become an entrepreneur and equip would-be entrepreneurs with relevant skills (Lorz; Mueller; Volery, 2013). Most studies support this hypothesis, and conclude that entrepreneurship education has a positive impact on entrepreneurial intentions and behaviors (Liao; Gartner, 2007). Nevertheless, this stance does not imply that entrepreneurial education can create the next Spanish generation of Mark Zuckerbergs, Steve Jobs, or Larry Pages. Instead, most of the programs are aimed at teaching students to put theory into practice and to better understand entrepreneurship (Meyer, 2011). In this way, according to Sánchez (2013), students are expected to gain self-confidence and motivation to establish their own business ventures, become proactive, creative, and learn how to work in a team.

On the other hand, the multiplication of entrepreneurship programs has generated a growing interest from fund providers and academics about issues of effectiveness and efficiency in these programs, as well as the identification and diffusion of best practices (Fiet, 2001). In this sense, despite the importance of the political and educational promotion of entrepreneurship programs, to our knowledge, there has been a noticeable lack of research into entrepreneurship programs that have been exclusively designed for students pursuing journalism studies. In addition, very little is known about the specific impact of such programs on students' intentions and the possibilities of their adoption by other different universities.

In this paper, we empirically examine how a specific entrepreneurship program influenced the entrepreneurial intentions of journalism students from the Carlos III University of Madrid. In total, 138 students participated in the study: 88 were in the experimental group and 50 in the control group. We conducted a pre-post-test in order to describe in detail, and empirically validate an entrepreneurship program specifically designed to promote an entrepreneurial career path in journalism.

With these goals in mind, the paper is structured as follows: initially, we present a theoretical framework in which we describe the recent literature on entrepreneurial intention and entrepreneurship education programs; this leads to our research question: Does Joupreneur significantly increase the entrepreneurial intention of students pursuing journalism studies? Subsequently, we present the methodology of the research and describe in detail the organization, contents, and evaluation system of Joupreneur. We then present the results and, finally, we link the findings with the wider entrepreneurship education literature.

\section{Theoretical framework}

\subsection{Entrepreneurial intention and entrepreneurship education programs}

Despite the wide-ranging debate regarding the theoretical framework for analyzing intentions (Thompson, 2009), the vast majority of empirical models depart from the theory of planned behavior (Ajzen, 1991). In this sense, intention would be a decisive and determinant element in predicting behaviors (Fayolle; DeGeorge, 2006). Any planned behavior is best predicted by observing intentions towards that behavior, not by measuring attitudes, beliefs, personality traits, or demographics (Bagozzi; Baumgartner; Yi, 1989). Therefore, the prediction of future behavior should be obtained through the measurement of this intention which, in our case, is the intention to become an entrepreneur. Based on this logic, entrepreneurial intention could be conceptualized as the self-acknowledged conviction or intent "to set up a new business venture and consciously plan to do so at some point in the future" (Thompson, 2009, p. 676). However, depending on what people learn (in this case on what students learn) entrepreneurial intentions can be enhanced or diminished (Von-Graevenitz; Harhoff; Weber, 2010).

In the context of this study we define entrepreneurship education programs as any pedagogical program or process of education for entrepreneurial attitudes and skills, which involves developing certain personal qualities (Fayolle; Gailly; Lassas-Clerc, 2006). This definition is not exclusively focused on the immediate creation of new business ventures and it covers a wide variety of situations, aims, methods, and teaching approaches. Based on these preliminary observations, we draw, in our research, on Donckels' (1991) claim that at the university level the principal role of entrepreneurship education programs is to increase student awareness and to highlight the entrepreneurial path as a viable career option. The purpose of this study is to test the impact of a specific 
program (Joupreneur) on the entrepreneurial intentions of students pursuing journalism studies.

Previous empirical studies have focused their analysis on the general theme of entrepreneurial education and entrepreneurial intention. Results show a widespread consensus regarding the positive effect of entrepreneurial education programs on entrepreneurial intention, but the evidence is still not strong. Some empirical studies do confirm that there is a positive impact of entrepreneurship education courses or programs at universities on perceived attractiveness and perceived feasibility of new venture initiation (Tkachev; Kolvereid, 1999). However, other studies find evidence that the effects are negative (Oosterbeek; Van-Praag; ljsselstein, 2010). In this sense, there may be methodological reasons why the literature has not yet generated consistent assessments on this topic (Von-Graevenitz; Harhoff; Weber, 2010). One such methodological limitation is the focus on self-selected participants with some existing predisposition towards entrepreneurship, which is likely to bias results in favor of educational intervention (Gorman; Hanlon; King, 1997). But above all, the main limitation is that few studies employ a pre-post design, and even fewer use a control group.

Despite these limitations there is a general consensus in the academic literature about the positive relationship between entrepreneurial education programs and entrepreneurial intention (Souitaris; Zerbinati; Al-Laham, 2007). However, it remains to be seen whether and how those results can be generalized to various settings, such as journalism. Based on this, we proposed the following research question: Does Joupreneur significantly increase the entrepreneurial intentions of students pursuing journalism studies?

\section{Methodology of the study}

\subsection{About the course}

"Organization and Management of Media Enterprises" is a mandatory course that is worth 6 ECTS practical-theoretical credits and is offered in the third year of the BA degree in journalism and bilingual journalism at the Carlos III University of Madrid. The course is based on the methodology that have been developed for years by Javier Galán, Guadalupe Aguado, José Fernández-Beaumont and Enrique Bullido. The course theoretically explores basic business concepts that are required in order to design, develop, and manage a media company in a relatively competitive and realistic environment. The course has a practical and didactic approach and each topic includes case studies and exercises that help students to understand the theoretical contents under study. In general, the main objective of the course is to provide students with the basic and fundamental theoretical and conceptual tools to develop new business ventures in a relatively real and competitive context.

\subsection{Procedure}

Intention towards entrepreneurship was analyzed with four different groups of students that took the mandatory course "Organization and Management of Me- dia Enterprises" in the first semester of the academic year $2014 / 2015$. Of the four groups, three of them were taught in Spanish, whilst the fourth one was in English. In the English group, the origin of the students was as follows (most of the non-Spaniards were part of the international program): USA ( $n=1 ; 4.76 \%)$, Portugal $(n=2 ; 9.52 \%)$, Australia $(n=2$; $9.52 \%)$, Germany ( $n=3 ; 14.28 \%)$, England ( $n=5 ; 23.80 \%)$, and Spain $(n=8 ; 38.09 \%)$. The total number of students in all four courses amounted to 120 , of which 88 were surveyed (the response rate was $73.33 \%$ ). The total sample of 88 students included slightly more women ( $n=61 ; 69.3 \%$ ) than men ( $n=27,30.7 \%$ ), a gender distribution that aligns with the vast majority of journalism courses in Spanish universities. The average age was 20.79 (max.: 33; min.: 19).

The distribution of the students by group was as follows: a total of 25 students were surveyed in group one, 21 students were surveyed in group two (in the bilingual journalism BA degree), a total of 23 students were surveyed in group three, and 19 in the fourth group. The same students participated in both the pre and post-test. As previously stated, the surveys were conducted at the beginning and end of the first semester of the 2014/2015 academic year in all four groups. Data for the pre-test was collected on the $15^{\text {th }}$ of September of 2014 while data for the post-test was collected on the $15^{\text {th }}$ of December 2014, that is, three months later and after Joupreneur.

With respect to the control group, we chose 50 journalism students who took the same subject in a different public Spanish university. The rationale to this selection was the fact the students had similar demographic characteristics and the subject was imparted in the same degree, but with a different learning methodology and topics covered. The control group was formed by 28 women (56\%) and 22 men (44\%) with an average age of 22 (max: 27; min: 21).

Different methodological approaches have been used to examine differences between treatment and control groups. However, we use the methodological approach proposed by Souitaris, Zerbinati, and Al-Laham (2007) because it meets a high standard of methodological rigor (Martin; MacNally; Kay, 2012) and it is more suited to our interests. Thus, to test the effect of the program on the changes in intentions, we used one-way anova on the difference scores (total sample) with group membership (experimental versus control) as the independent variable. The "difference scores" method is preferable to split-plot repeated measures anova for pretest-posttest designs with "treatment" and control groups as it gives equivalent results in a simpler and less confusing way (Girden, 1992).

Table 1. Demographic characteristics

\begin{tabular}{|l|c|c|c|c|c|c|}
\hline & \multicolumn{2}{|c|}{$\begin{array}{c}\text { Experimental } \\
(\mathbf{N}=\mathbf{8 8})\end{array}$} & \multicolumn{2}{c|}{$\begin{array}{c}\text { Control } \\
(\mathbf{N = 5 0 )}\end{array}$} & \multicolumn{2}{c|}{$\begin{array}{c}\text { Total } \\
\text { (N= 138) }\end{array}$} \\
\hline & No & Percent & No & Percent & No & Percent \\
\hline Sex & 88 & 100 & 50 & 100 & 138 & 100 \\
\hline Men & 27 & 30.7 & 22 & 44 & 49 & 35.50 \\
\hline Women & 61 & 69.3 & 28 & 56 & 89 & 64.49 \\
\hline Age $(\mathrm{m})$ & 20.79 & & 22 & & 21.30 & \\
\hline
\end{tabular}




\section{Joupreneur program}

The duration of the course is 14 weeks, with one three-hour class per week. The course design is identical for all the groups and complies with the following pattern. From the beginning, according to their number (usually around 25), the students are randomly divided into three or four groups of 6-8 members and they start working on the idea of a business project in the media industry that will be presented at the end of the term. In the first part of the course (weeks 1-6) classes are divided into two equal parts: during the first half, the lecturer introduces some theoretical concepts and managerial tools, whereas the second part is dedicated to team-work skill-building and students try to apply these notions to their projects, which grow week by week.

The different teachers are free to organize their lectures according to their own personal inclinations, but they all typically cover the following topics: mission, vision and values of the company; industry analysis; product development and innovation process; value chain and competitive advantage; organizational structure and marketing. The contents tackled in the lectures provide an introduction to management for journalists and represent a guide for the realization of the final project, a 5 to 10 pages document, which is organized as follows: First, it must contain a mission statement, a vision statement, and a values statement of the company. The second part is dedicated to an analysis of the industry in which the firm is entering, of its direct competitors, and of their potential response. In the third section of the project, the students must describe the company's value chain and core processes, its position in the value system and then indicate how they think it is possible to achieve a competitive advantage in the chosen industrial sector. After this, the document illustrates the formal organization of the firm and provides a possible salary frame. The successive paragraph deals with the competitive strategy of the company and its middle-term strategy. Then there is a description of the launching process and of the launching timing plan, illustrated by a Gantt chart. The following section of the project envisions a marketing strategy and the last one examines the sources of revenues that are expected to provide profitability. Given that the course is part of a journalism degree, no financial analysis is required. Above all, the final project design attempts to give a taste of what an entrepreneurial process can be and it provides students their first introduction to basic managerial tools.

The second part of the course (weeks 7-11) is characterized by the absence of lectures and every week each group presents a different study on a national media industry. Ideally, the chosen country coincides with the one in which the group is considering as the place to start the final project's company, but this is not mandatory. The first presentation is dedicated to the press industry, then the industries of radio, television, and advertising are covered; lastly, the groups provide a general framework of the chosen national media industry ${ }^{1}$.

Every member must participate in the public presentation, which lasts 25-30 minutes and is accompanied by a multimedia document (no longer than 10 slides) and a two-sheet pdf document containing subsidiary information and all the sources of the data ${ }^{2}$. At the end of each presentation, the teacher comments on the research and a class discussion follows. Also, the other groups deliver a brief written analysis/consideration and an evaluation of the presentation to the lecturer. These "peer-reviews", that may or may not be taken into account by the teacher, have the purpose of maintaining the attention of the students and motivating a critical view.

Overall, the goal of these five presentations is to develop the ability of studying a media industry from an entrepreneurial point of view, of providing a concise account of its situation, and of seeing the business opportunities within the distinct sectors. This also aims to improve the final projects, which acquire details and background information during these weeks.

The class of week twelve is dedicated to a group tutorship in which each team receives final advice and feedback from the teacher. Then, on the last two days of class, students work in teams to give 30-45 minute public presentations of their final projects.

\section{Evaluation system}

The final grade is the result of the team's work, which is evaluated during the course of the quarter, and of a final individual exam. Both the exam and the continuous evaluation account for half of the final grade, which is expressed, according to the Spanish system, in a 0-10 scale where 5 is the minimum mark needed to pass. The final exam consists of 10 questions about the topics covered in the lectures and a reference book [Organización y gestión de la empresa informativa by Aguado-Guadalupe et al. (2008) for the Spanish group and Strategic management in the media: Theory to practice by Lucy Küng (2008) for the English group].

The final project accounts for $25 \%$ of the grade and its mark is up to 250 points. To avoid cases of free-riding, this mark is multiplied by the number of the members in the groups and the students split it and share it according to the perceived individual contribution. So, if the final project grade is 200 and the group has 6 members, the mark will be 1200, and the individual marks may be 200 for everybody if the group agrees to share equally, or may be different in case it decides otherwise. Finally, each of the five presentations of the national media industry account for $5 \%$ of the final grade. Their marks are up to 50 and they follow the same sharing rule of the final project's grade.

\section{Results}

Prior to conducting the experimental analysis, we analyzed both pre and post data. The mean scores of the entrepreneurial intention are very similar in pre data (in ascending order): course 3 has the lowest entrepreneurial intention $(m=2.13$; $S D=1.14)$, followed by course $1(m=2.48 ; S D=1.12)$, course 2 ( $m=2.61 ; S D=1.11)$, and finally course 4 has the highest entrepreneurial intention ( $m=2.84 ; S D=0,95)$. The mean of the entrepreneurial intention in all courses in pre data is 2.50 $(S D=1.10)$. With regard to the control group the mean scores of the entrepreneurial intention is $2.40(S D=1,16)$. 


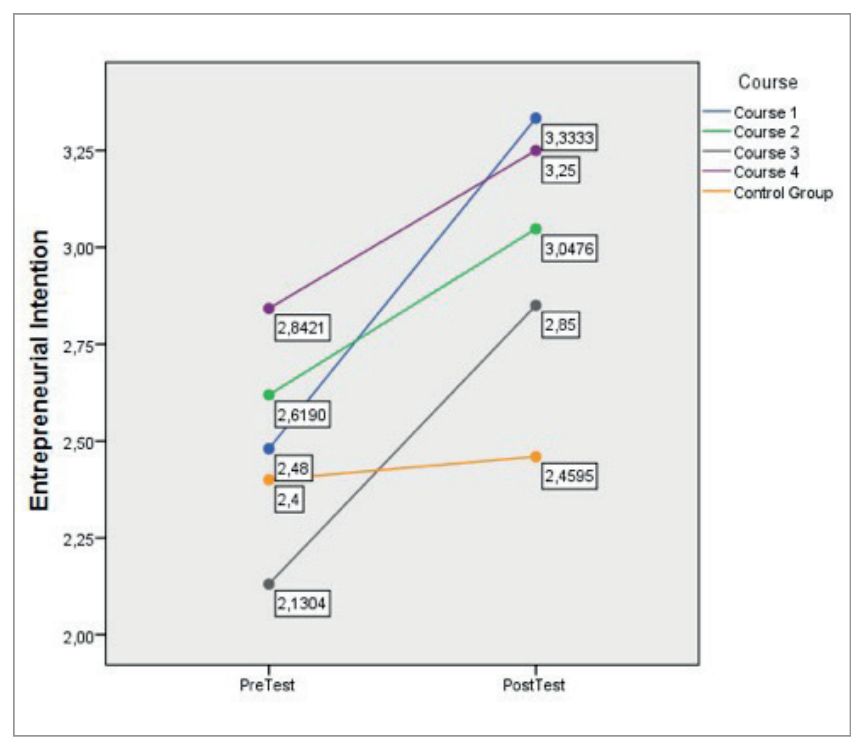

Figure 4. Pre and post-data in the four groups and the control group.

In relation to the post analysis, data is very similar with regard to the parity between means of entrepreneurial intention, although there is a notable increase with respect to pre data (to be in ascending order): course 3 has the lowest mean in entrepreneurial intention in post data $(m=2.85 ; S D$ $=1.13)$, followed by course $2(m=3.04 ; S D=1.02)$, course $4(m=3.25 ; S D=1.01)$ and finally, course $1(m=3.33 ; S D=$ 1.06) has the highest entrepreneurial intention. The mean of the entrepreneurial intention in all four courses in post data is $3.12(S D=1.05)$. On the other hand, the mean scores of the control group are very similar to pre data $(m=2.45$; $S D=1.19$ ) suggesting, a priori, no significant differences.

As we previously noted, the data of the entrepreneurial intention scores in pre data was $2.50(S D=1.10)$ while in post data was $3.12(S D=1.05)$. To verify if our methodology (Joupreneur) significantly increases the entrepreneurial intention among journalism students we conduct a one-way analysis of variance (anova) for the entire sample. Our results indicate that there are significant differences in relation to the pre/post scores and the level of entrepreneurial intention $(p<0.05)$. Furthermore, there is no significant difference between the level of entrepreneurial intention between pre and post data in the control group. Therefore, we conclude that Joupreneur increases the overall entrepreneurial intention among journalism students.

\section{Discussion}

The present article is one of the first studies to describe in detail, and empirically validate a methodology for raising the entrepreneurial intention among journalism students. Based on pre-post surveys of four different groups of students (in total), ages 18 to 25, from the Carlos III University of Madrid, this study measured the change in students' intentions after a period of three months of Joupreneur, that is, the entrepreneurship program implemented.

First, this study shows a generally low entrepreneurial intention among the students pursuing journalism studies in
Spain. After Joupreneur, the analysis of variance (anova) suggests a significant increase in intention in relation to predata, even if it still remains low. If intention is considered to be one of the most important predictors of future behavior (Ajzen, 1991), self-employment as a career path in the journalism sector remains as a subordinate labor alternative. Therefore, being a salaried employee continues to be deemed as one of the most important and desirable labor preferences for future professionals.

There are several different reasons that might explain this lack of entrepreneurial intention. Between them, we can highlight the lack of educational support for the students pursuing journalism studies in developing new business ventures, the current Spanish socioeconomic context, and the professional culture of this particular sector (their habits, experiences, and lifestyles). In particular, we consider that the most important factor in determining low entrepreneurial intention is the security provided by the sense of belonging to a workforce, that is, the vision of journalism as an occupation that implies working as an employee in a traditional media company.

In Spain, journalism studies' curricula promote a system of internships in news organizations that start from the early years of the bachelor's degree. Beyond its utility for professional development - something that doesn't concern the scope of this article- it could be suggested that this educational model acts as an inhibitor of future entrepreneurial behaviors. Taking into account the current situation of the sector, this strategy might not be the best for giving the students an opportunity to find a job in the journalism industry. On the contrary, in these days of economic instability, where media companies tend to implement radical austerity measures fundamentally through layoffs and wage cuts, the promotion of entrepreneurship as a preferred career path for future professionals of the journalism sector can be seen as a possible solution (Goyanes, 2014; Manfredi-Sánchez; Rojas-Torrijos; Herranz-de-la-Casa, 2015).

The current Spanish situation of the news industry leaves no room for doubt. Between 2008 and 2013, 284 news organizations were closed and the unemployment rates have increased by $132 \%$. In 2013 alone, 4,434 reporters were dismissed and 73 news organizations disappeared. Nevertheless, in 2012, 2,909 new journalists graduated. Given this data and according to our research, we would suggest the implementation by academic institutions of complementary programs aimed at changing the students' traditional expectations. We believe that a stronger focus on entrepreneurship would provide students with an alternative mental framework while showing a different approach to their prospective careers. To achieve this goal, the universities may, for example, introduce some courses oriented to the development of entrepreneurial attitudes from the beginning of the degree, encourage extracurricular activities focused on entrepreneurship, or create master's degrees or curricula with a strong emphasis on self-employment. As a result, we could witness the creation of new environments and professional fields where the skills acquired during the journalism degree could flourish. 
Moreover, our research shows how increases in entrepreneurial intentions may be caused by the implementation of simple managerial and entrepreneurial tools and concepts. This is to say, to increase the entrepreneurial intention of journalism students it is sufficient enough to merely create awareness that being an employee in a traditional media company is not the only career option available.

\section{Notes}

1. For a better understanding of the details, we briefly describe here the structure of the presentation:

1) The press industry: evolution of the industry; industry's volume (readers and advertisement investments); general audience's evolution (last 5-10 years minimum); cost structure; revenues structure; promotion / marketing; industry analysis (Michael Porter's 5 competitive forces); impact of digital media; segmentation and regionalization; business opportunities.

2) The radio industry: regulation of the industry; volume of the industry (listeners and advertising investments); evolution of the audiences; timeline of daily consumption (who watches what at what time); industry analysis; segmentation of the contents and the markets; radio station groups; digital radio; business opportunities.

3) The television industry: regulation of the industry (including advertising regulation); volume of the industry (audiences and advertising investments); evolution of the audiences; timeline of daily consumption; segmentation of the contents and the markets; television groups; industry analysis; new ways of watching television; business opportunities.

4) The advertising industry: regulation; evolution of the investments in all media industries (general overview), in each traditional media industry (radio, television, press), and by advertisers; structure of the industry (number and size of companies); factors in media selection; new advertising trends in traditional media companies and new media companies.

5) General framework: presentation that provides a description of the present situation of the national media industry mostly using data gathered in previous weeks. The primary aim is to highlight the most important features of the industry and, secondly, present the business opportunities within the industry.

2. These restrictions are not applied in the case of the last presentation.

\section{References}

Aguado-Guadalupe, Guadalupe et al. (2008). Organización y gestión de la empresa informativa. Madrid: Síntesis. ISBN: 9788497566025

Ajzen, Icek (1991). "The theory of planned behavior". Organizational behavior and decision processes, v. 50, n. 2, pp. 179-211. http://dx.doi.org/10.1016/0749-5978(91)90020-T

Bagozzi, Richard; Baumgartner, Hans; Yi, Youjae (1992). "State versus action orientation and the theory of reasoned action: an application to coupon usage". Journal of consumer research, v. 18, n. 4, pp. 505-518.

http://dx.doi.org/10.1086/209277

Donckels, Rik (1991). "Education and entrepreneurship experiences from secondary and university education in Belgium". Journal of small business \& entrepreneurship, v. 9, n. 1, pp. 35-42.

http://dx.doi.org/10.1080/08276331.1991.10600389

Fayolle, Alain; Degeorge, Jean-Michel (2006). "Attitudes, intentions, and behaviour: New approaches to evaluating entrepreneurship education". En: Fayolle, Alain; Klandt, Heinz. International entrepreneurship education. Issues and newness. Cheltenham, UK: Edward Elgar Publishing, pp. 74-89. ISBN: 9781845421793 http://goo.gl/GD4xWr

Fayolle, Alain; Gailly, Benoit; Lassas-Clerc, Narjisse (2006). "Assessing the impact of entrepreneurship education programmes: a new methodology". Journal of European industrial training, v. 30, n. 9, pp. 701-720.

http://dx.doi.org/10.1108/03090590610715022

Fiet, James (2001). "The theoretical side of teaching entrepreneurship". Journal of business venturing, v. 16, n. 1, pp. $1-24$.

http://dx.doi.org/10.1016/S0883-9026(99)00041-5

Galán-Gamero, Javier; Aguado-Guadalupe, Guadalupe (2014). Periodismo emprendedor: planificación y desarroIlo de empresas informativas. Madrid: McGraw-Hill. ISBN: 9788448190392

Girden, Ellen R. (1992). Anova: Repeated measures. Thousand Oaks, CA: Sage. ISBN: 9780803942578

Gorman, Gary; Hanlon, Dennis; King, Wayne (1997). "Some research perspectives on entrepreneurship education, enterprise education and education for small business management: a ten-year literature review". International small business journal, v. 15, n. 3, pp. 56-77.

http://dx.doi.org/10.1177/0266242697153004

Goyanes, Manuel (2015). “Apoyo estructural en la intención emprendedora de estudiantes de periodismo y comunicación audiovisual en España". El profesional de la información, v. 24, n. 1, pp. 55-61.

http://dx.doi.org/10.3145/epi.2015.ene.07

Küng, Lucy (2008). Strategic management in the media: Theory to practice. London: Sage. ISBN: 1412903130

Liao, Jianwen; Gartner, William B. (2007). "The influence of pre-venture planning on new venture creation". Journal of small business strategy, v. 18, n. 2, pp. 1-21.

https://www.questia.com/read/1P3-1462628221/theinfluence-of-pre-venture-planning-on-new-venture

Lorz, Michael; Mueller, Susan; Volery, Thierry (2013). "Entrepreneurship education: a systematic review of the methods in impact studies". Journal of enterprising culture, v. 21, n. 2 , pp. $123-151$. http://dx.doi.org/10.1142/S0218495813500064

Lüthje, Christian; Franke, Nikolaus (2004). “Entrepreneur- 
ial intentions of business students: A benchmarking study". International journal of innovation and technology management, v. 1, n. 3, pp. 269-288.

http://epub.wu.ac.at/3097/1/entrepreneurial_intentions_ benchmark.pdf

Manfredi-Sánchez, Juan-Luis; Rojas-Torrijos, José-Luis; Herranz-de-la-Casa, José-Luis (2015). “Innovación en el periodismo emprendedor deportivo. Modelo de negocio y narrativas". El profesional de la información, v. 24, n. 3, pp. 265-273.

http://dx.doi.org/10.3145/epi.2015.may.06

Martin, Bruce C.; McNally, Jeffrey J.; Kay, Michael J. (2012). "Examining the formation of human capital in entrepreneurship: A meta-analysis of entrepreneurship education putcomes". Journal of business venturing, v. 28, n. 2, pp. 211-224.

http://dx.doi.org/10.1016/j.jbusvent.2012.03.002

Meyer, G. Dale (2011). "The reinvention of academic entrepreneurship". Journal of small business management, Special issue: Global research and policy implications for today's SMEs, v. 49, n. 1, pp. 1-8.

http://dx.doi.org/10.1111/j.1540-627X.2010.00311.x

Oosterbeek, Hessel; Van-Praag, Mirjam; ljsselstein, Auke (2010). "The impact of entrepreneurship education on entrepreneurship skills and motivation". European economic review, v. 54, n. 3, pp. 442-454.

http://dx.doi.org/10.1016/j.euroecorev.2009.08.002

Sánchez, José C. (2013). "The impact of an entrepreneur- ship education program on entrepreneurial competencies and intention". Journal of small business management, v. 51, n. 3, pp. 447-465.

http://dx.doi.org/10.1111/jsbm.12025

Souitaris, Vangelis; Zerbinati, Stefania; Al-Laham, Andreas (2007). "Do entrepreneurship programmes raise entrepreneurial intention of science and engineering students? The effect of learning, inspiration and resources". Journal of business venturing, v. 22, n. 4, pp. 566-591.

http://dx.doi.org/10.1016/j.jbusvent.2006.05.002

Thompson, Edmund R. (2009). "Individual entrepreneurial intent: Construct clarification and development of an internationally reliable metric". Entrepreneurship theory and practice, v. 33, n. 3, pp. 669-694.

http://dx.doi.org/10.1111/j.1540-6520.2009.00321.x

Tkachev, Alexei; Kolvereid, Lars (1999). "Self-employment intentions among Russian students". Entrepreneurship \& regional development, v. 11, n. 3, pp. 269-280.

http://dx.doi.org/10.1080/089856299283209

Von-Graevenitz, Georg; Harhoff, Dietmar; Weber, Richard (2010). "The effects of entrepreneurship education". Journal of economic behavior \& organization, v. 76, n. 1, pp. 90-112. http://dx.doi.org/10.1016/j.jebo.2010.02.015

Zahra, Shaker; Wright, Mike; Abdelgawad, Sondos (2014). "Contextualization and the advancement of entrepreneurship research". International small business journal, v. 32, n. 5, pp. 479-500.

http://dx.doi.org/10.1177/0266242613519807

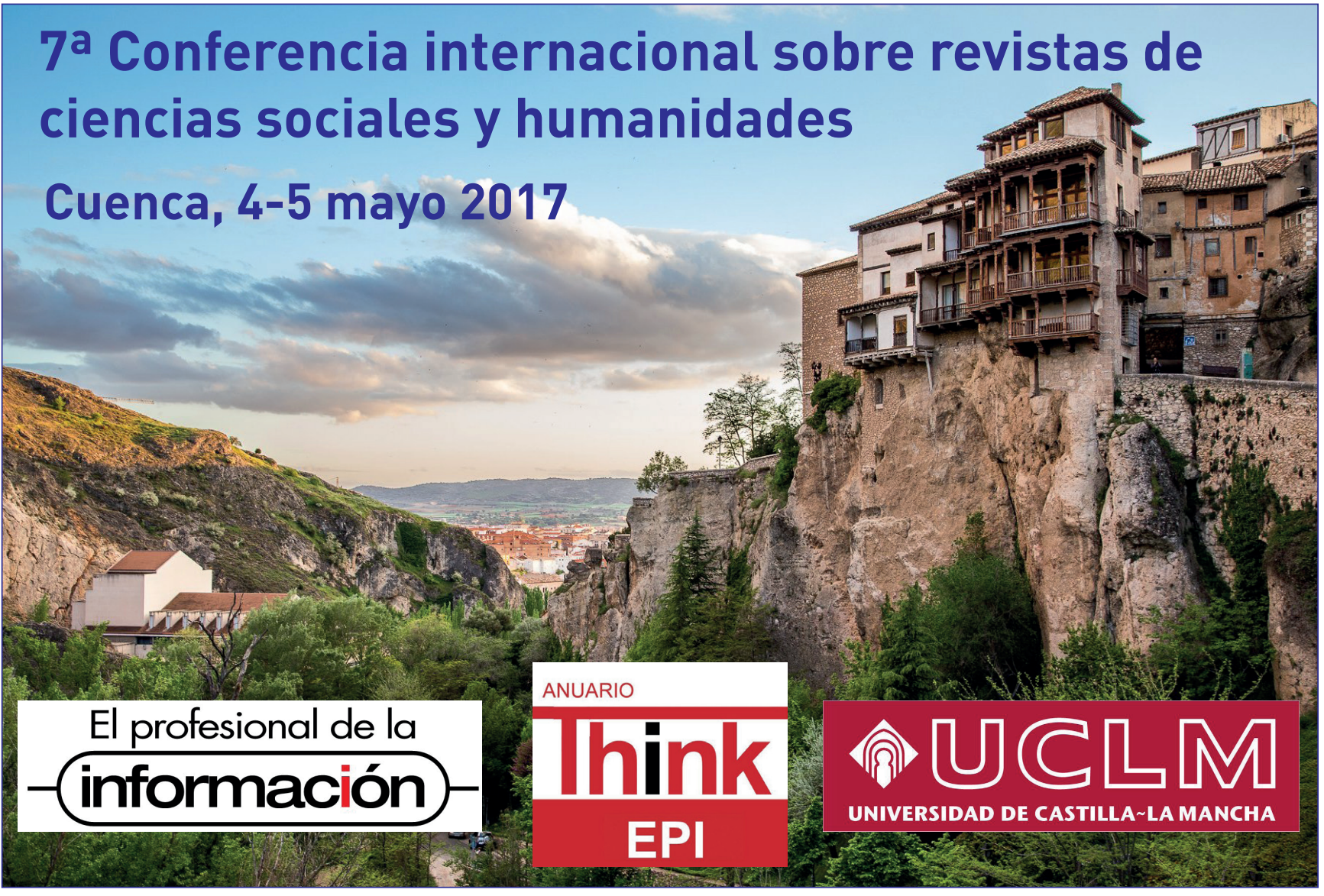

